\title{
MORPHOLOGY AND ANATOMY OF DEVELOPING FRUITS AND SEEDS OF Mammea americana L. (CLUSIACEAE)
}

\author{
MOURÃO, K. S. M. ${ }^{1}$ and BELTRATI, C. M. ${ }^{2}$ \\ ${ }^{1}$ Departamento de Biologia, Universidade Estadual de Maringá, CEP 87020-900, Maringá, Paraná, Brazil \\ ${ }^{2}$ Departamento de Botânica, Instituto de Biociências, Universidade Estadual Paulista, C.P. 199, CEP 13506-900, \\ Rio Claro, São Paulo, Brazil \\ Correspondence to: Káthia Socorro Mathias Mourão, Departamento de Biologia, Universidade Estadual de Maringá, \\ Av. Colombo, 5790, CEP 87020-900, Maringá, Paraná, Brazil, e-mail: ksmmourao@vem.br \\ Received November 16, 1999 - Accepted January 31, 2000 - Distributed November 30, 2000
}

(With 35 figures)

\begin{abstract}
Morphological, structural and developmental features of fruits and seeds of Mammea americana $\mathrm{L}$. are here studied, with the purpose to give a proper classification of their fruit and embryo type and to contribute to future taxonomical and ecological studies. The fruit is a berry and the "rind" consists of the exocarp, represented by a periderm with lenticels, and by the parenchymatic mesocarp, with branched secretory ducts and vascular bundles. The edible pulpy is formed by the endocarp, destituted of secretory ducts, and derived from the activity of a ventral meristem, which emerges early in the fruit development. The inner endocarp cell layers undergo a radial elongation and become firmly attached to the testal outer layers. At maturation the endocarp may be released from the rest of the pericarp. The ovules are unitegmic and they turn into unitegmic and exalbuminous seeds. The multiseriate testa consists of thick-walled cells and sclerenchymatous fibers. This last features have carried out to a wrong interpretation that the fruit of this species is a drupe. The embryo is pseudo-conferruminate, with two massive foodstoring cotyledons, rich in starch, firmly attached.
\end{abstract}

Key words: Clusiaceae, fruit, seed, Mammea, anatomy.

\section{RESUMO}

\section{Morfologia e anatomia dos frutos e sementes em desenvolvimento de Mammea} americana L. (Clusiaceae)

Descreveu-se, detalhadamente, a morfologia e a anatomia dos frutos e sementes, em desenvolvimento, de Mammea americana L., de modo a identificar corretamente o tipo de fruto e de embrião desta espécie, bem como contribuir com futuros estudos taxonômicos e ecológicos do grupo. $\mathrm{O}$ fruto desta espécie é uma baga, cuja "casca" é constituída pelo exocarpo, representado por uma periderme com lenticelas, e pelo mesocarpo, percorrido longitudinalmente por dutos secretores e feixes vasculares. O endocarpo, desprovido de dutos, origina-se da atividade de um meristema ventral e da epiderme interna do ovário. Suas células posteriormente se alongam em sentido radial, transformando-se na polpa amarelada, comestível, rica em açúcares e fibras, aderida à testa fibrosa. Os óvulos anátropos, unitegumentados originam sementes unitegumentadas e exalbuminosas. A testa multisseriada, constituída por parênquima de parede espessada e fibras esclerenquimáticas alongadas acompanhando os feixes vasculares muito ramificados, confere à semente o aspecto fibroso externo. Esta característica levou à interpretação errônea de que o fruto desta espécie seria uma drupa. O embrião é pseudo-conferruminado e constituído pelos cotilédones carnosos, fusionados.

Palavras-chave: Clusiaceae, fruto, semente, Mammea, anatomia. 


\section{INTRODUCTION}

Mammea americana (Clusiaceae) is an arboreal species, native of Antilhas (Huber, 1904/ 1906; Calzavara, 1970; Van Roosmalen, 1985) and has been cultivated in the north and northeast of Brazil dues to its fruit, which contains a yellowreddish, aromatic and edible pulp (Pio Corrêa, 1926; Rodrigues, 1989).

Characters of fruits and seeds have been used in the delimitation of subfamilies and tribes of Clusiaceae (Engler, 1888; Engler \& Keller, 1925; Melchior, 1964; Heywood, 1985). The lack of embryological detailed researches of fruits and seeds in this family has generated doubts about the position of the species in the subfamilies. Mammea americana was included by Engler (1888), by Engler \& Keller (1925) and by Melchior (1964) in Calophylloideae, who described the fruit as a berry and the embryo with fleshy and united cotyledons. However, Heywood (1985) placed this species in the tribe Garcinieae (Clusioideae), characterized by a drupe-like fruit.

In view of the exposed, in the present study, the fruits and seeds in development of Mammea americana are here described in full detail, with the purpose to elucidate its fruit and embryo type, and therefore to help its correct positioning inside of the family.

\section{MATERIAL AND METHODS}

The botanical material used in the present work consisted of floral buds, flowers and fruits of Mammea americana L., in different development stages.

\section{Studied material}

Mammea americana L.: Brazil, São Luís, Maranhão, $2^{\circ} 32^{\prime} \mathrm{S}$ and $44^{\circ} 17^{\prime} \mathrm{W}$, rural property, km 15, MA - 201, col. K. S. M. Mourão 2, I. 1994 , flowers, seedlings (HRCB 17420); col. K. S. M. Mourão 5, 26. I. 1996, flowers, seedlings (HUM 3448).

The morphologic characters of the fruits and seeds were described and illustrated, starting from 50 units of fresh material, collected from five individuals. For the dimensions measurements (length and diameter) of the fruits and seeds, a pachymeter was used, and the fresh weight was obtained with a electronic scale. It was also determined the number of seeds per fruit. The arithmetic average and the deviation-pattern were calculated for each one of the obtained variables. The nomenclature to describe the fruits and seeds patterns was based in Radford et al. (1974). The description of the fruit type was based in Spjut (1994).

In the morphological and anatomical studies the material was fixed and conserved in FAA $50 \%$ (Johansen, 1940) and Ethanol 70\% (Jensen, 1962), respectively. The anatomical description was made analyzing semi-permanent and permanent slides made with traverse and longitudinal sections of the pericarp and the seeds. The slides, the specific stains and reagents and the illustrations were made in agreement with methodology described by Mourão \& Beltrati (1995a). It was also used in the preparation of permanent slides material included in glycol methacrylate according to the technique described by Gerrits (1991). These microtome sections were stained with Toluidine Blue O (O'Brien et al., 1965) and assembled in Permount. The terminology adopted to define the pericarp layers is in agreement with Roth (1977) and the nomenclature used in the seeds descriptions was that defined by Corner (1976) and modified by Schmid (1986).

\section{RESULTS}

\section{Fruit development}

The superior ovary of Mammea americana is constituted by two carpels and two locules, with two ovules each and axile basal placentation (Figs. 1-3). The outer epidermis shows cubic cells with outer periclinal walls slightly thickened and cutinized. The ovarian mesophyll is pluriseriate and composed by fundamental parenchyma with cells of varied sizes. It is longitudinally traversed, except for the inner part that defines the locule, for a number of ramified schizogenous secretory ducts (Figs. 10, 16, 22, 23). These ducts secrete a white-yellowish substance, rich in lipids and phenolic contents. Amphicribal and branched vascular bundles also traversed the ovarian mesophyll in all extension.

After the fertilization, all the floral whorls stays in the young fruit $(1,5 \mathrm{~cm} \times 1,5 \mathrm{~cm})$, and occur gradually the corola abscission with the fruit development. 


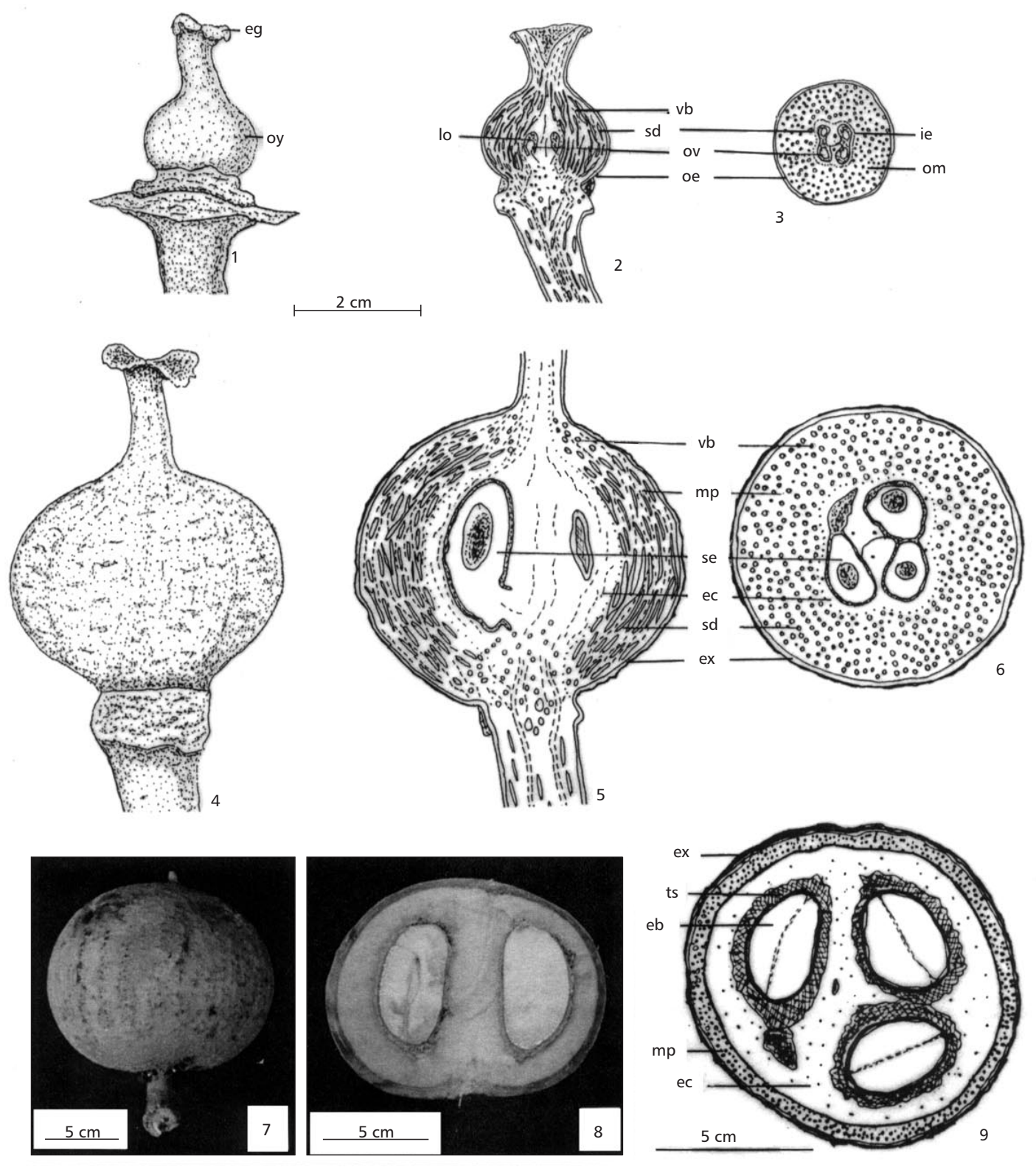

Figs. 1-9 - Mammea americana - General aspect, medium longitudinal and transversal sections, respectively, of the fruit development. 1-3 - Ovary. 4-6 - Young fruit $(3,0 \mathrm{~cm}$ x 3,0 cm). 7-9 - Mature fruit $(10,0 \mathrm{~cm} \mathrm{x} \mathrm{10,0} \mathrm{cm).} \mathrm{(eb} \mathrm{-} \mathrm{embryo;}$ ec - endocarp; eg - stigma; ex - exocarp; ie - inner epidermis; lo - locule; $\mathrm{mp}$ - mesocarp; oe - outer epidermis; om - ovarian mesophyll; ov - ovule; oy - ovary; sd - secretory duct; se - seed; vb - vascular bundle; ts - testa.)

The sepals and the stamens stay during a part of the development, standing out in the more developed fruit. The style persists for some time, remaining only part of it in the mature fruit (Figs. 4 and 7).
In this phase, the structure is basically the same of the ovary, having a small increase in the number of cellular layers and a larger differentiation of the area disproved of secretory ducts that delimits the locule. 

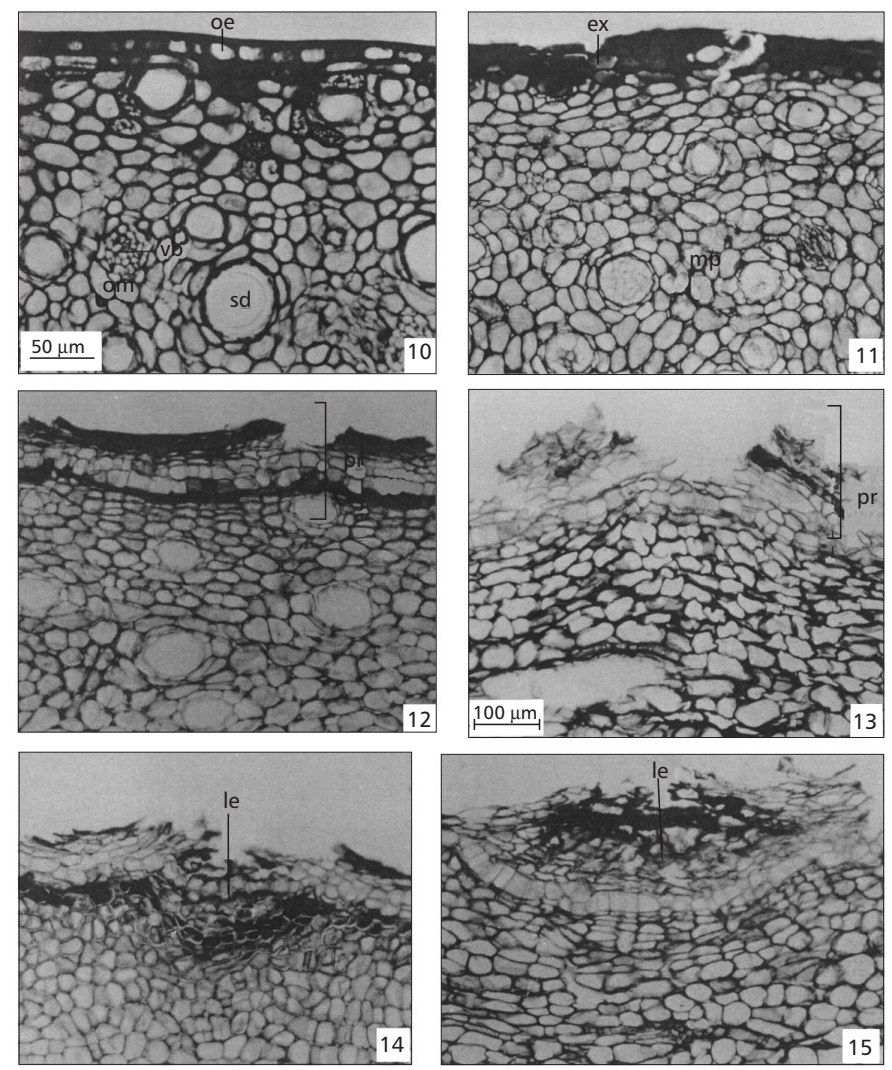

Figs. 10-15 - Mammea americana - Exocarp development. 10-11 - Ovary and Young fruit $(1,5 \mathrm{~cm} \times 1,5 \mathrm{~cm})$ in crosssection, respectively. 12-13 - Young fruit $(3,0 \mathrm{~cm} \times 3,0 \mathrm{~cm})$ in cross-section and mature fruit $(10,0 \mathrm{~cm} \times 10,0 \mathrm{~cm})$ in longitudinal section, evidencing the periderm. 14-15 - Young fruit $(3,0 \mathrm{~cm} \mathrm{x} \mathrm{3,0} \mathrm{cm)} \mathrm{in} \mathrm{longitudinal} \mathrm{section,} \mathrm{evidencing} \mathrm{periderm} \mathrm{and}$ lenticel in formation and developed, respectively. (ex - exocarp; le - lenticel; mp - mesocarp; oe - outer epidermis; om ovarian mesophyll; pr - periderm; sd - secretory duct; vb - vascular bundle.)

The uniseriate outer epidermis and the first subepidermical layers begin to arise the exocarp. The mesocarp, which derives of the ovarian mesophyll, stays parenchymatic. It is observed also, in the first outer subepidermical layers the occurrence of periclinals divisions and the exocarp starts to suberize (Fig. 11). In this phase, the beginning of the seeds development is observed.

In the young fruit $(3,0 \mathrm{~cm} \mathrm{x} 3,0 \mathrm{~cm})$, as well as in the completely developed, but still immature fruit $(10,0 \mathrm{~cm} \times 10,0 \mathrm{~cm})$ the seeds are already developed, occupying all the locule (Figs. 4-6). In these phases the exocarp is represented by two peridermics layers, where the phellogens and the cork are evident (Fig. 12) and lenticels are observed (Figs. 14 and 15). In the mature fruit, the most outer periderm is eliminated (Figs. 13 and 19). As in the ovary, in the mesocarp occurs secretory ducts, more numerous and anastomosed, forming a net, and also, brunched vascular bundles (Figs. 5, 6 and 12).

The endocarp is parenchymatic and derives from a ventral meristem, arised in the inner part of the ovarian mesophyll, and of the inner epidermis that delimits the locule. These layers are disproved of secretory ducts and show vascular bundles and cells with thin walls. Later, this cells undergo a radial elongation and with the seed development the endocarp make firmly attached to the fibrous testa (Figs. 16-18).

The fruit is a spherical to oblate berry with brown coloration and very wrinkled surface (Fig. 7). It measures $8,78 \pm 1,08 \mathrm{~cm}$ of length per 9,78 \pm $1,15 \mathrm{~cm}$ of diameter and presents $350,22 \mathrm{~g} \pm$ $120,81 \mathrm{~g}$ of weight of fresh matter. It contains one to four seeds per fruit (on the average 1,7 \pm $0,98)$. 


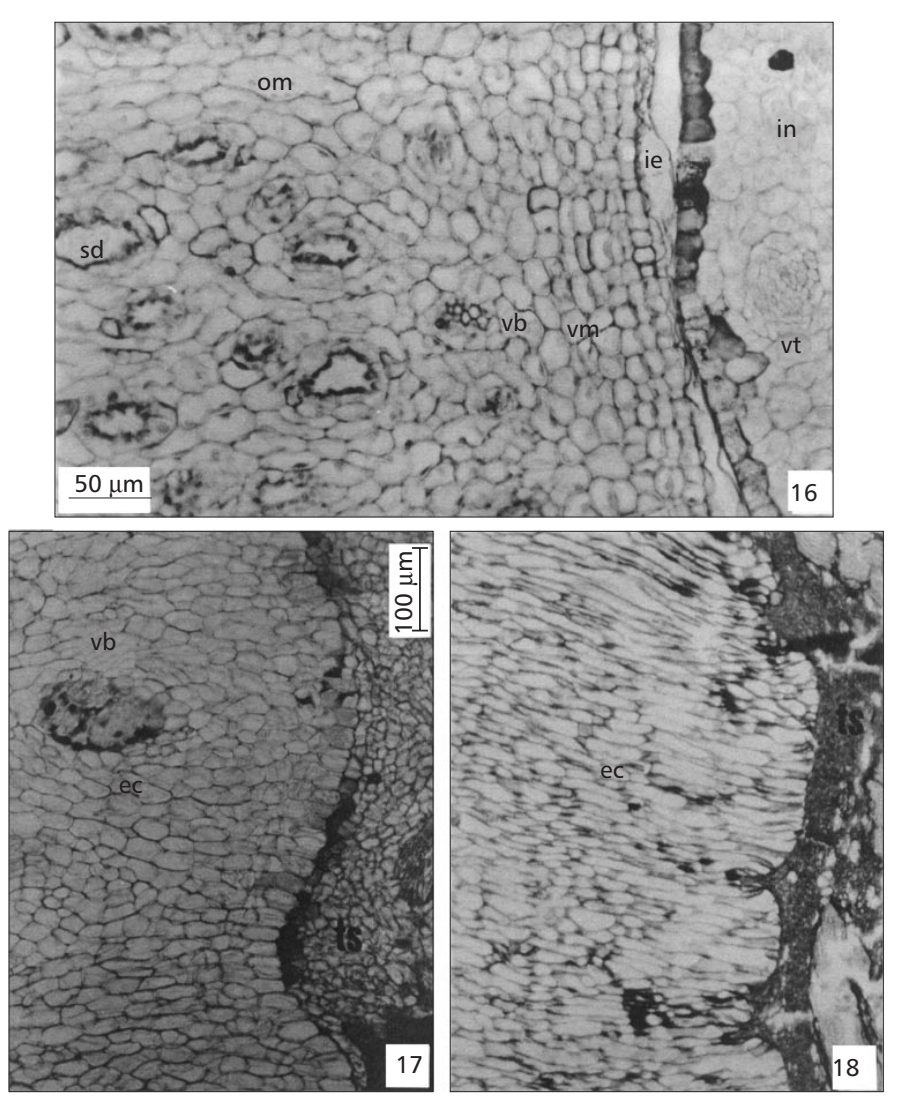

Figs. 16-18 - Mammea americana - Cross-sections showing the endocarp development. 16 - Ovary. 17 - Young fruit $(3,0 \mathrm{~cm} \times 3,0 \mathrm{~cm}) .18$ - Mature fruit $(10,0 \mathrm{~cm} \times 10,0 \mathrm{~cm})$. (ec - endocarp; ie - inner epidermis; in - integument; om ovarian mesophyll; sd - secretory duct; ts - testa; vb - vascular bundle; vm - ventral meristem; vt - vascular trace.)

The "rind" of the mature fruit is constituted by the exocarp, represented by the periderm, and by the mesocarp with branched secretory ducts and vascular bundles (Figs. 8, 9, 13, 19 and 20). The region where occur the separation of the "rind" of the remaining pericarp can be evidenced already in the ovarian mesophyll, among the outer region with secretory ducts and the inner disproved them (Figs. 16 and 20). The endocarp, firmly attached to the fibrous testa (Figs. 17, 18 and 21), becomes the yellowish and edible pulp, rich in sugars.

\section{Seed development}

The ovule of Mammea americana are anatropous and unitegmic. The only integument has about 26 layers of cells. The branched rapheal trace, when reaching the chalazal region emits postchalazal branches, which occur in the outer part of the integument (Figs. 24-28).
With the seed development, a clear increase in the number of vascular bundles occurs, which branches by the medium and outer region of the testa in all directions. Around the vascular bundles are observed slightly elongated cells with walls little thickened and in this phase still without lignin (Figs. 29 and 30). Later, these cells will differ in sclerenchymatic fibers (Fig. 31). The embryo in this initial stage is not still developed.

In the immature seed the inner layers of the testa becomes collapsed. The outer layers grow and emit deep projections in the endocarp. These projections make the testa firmly attached to the endocarp (Figs. 17, 18 and 31). The embryo already occupies the whole seminal cavity.

The seeds are ellipsoids, have brown coloration and show a fibrous testa. The hillum and the micropyle are obscure in the fibrous integument (Fig. 32). 

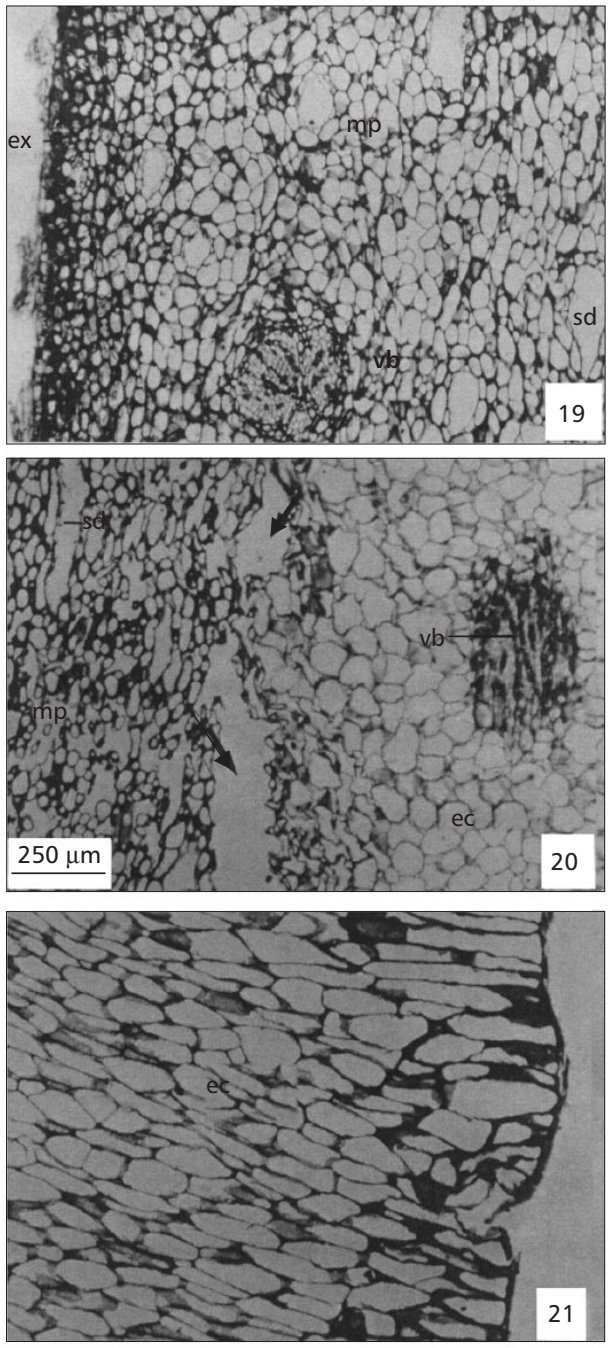

Figs. 19-21 - Mammea americana - Detail of the pericarp in the mature fruit. 19 - Cross-section evidencing the exocarp and part of the mesocarp. $\mathbf{2 0}$ - Longitudinal section evidencing the separation tissue (arrows) between the mesocarp and endocarp. 21 - Cross-section evidencing elongated cells of the endocarp. (ec - endocarp; ex - exocarp; mp - mesocarp; sd - secretory duct; vb - vascular bundle.)

They show, on the average, $5,68 \pm 0,67 \mathrm{~cm}$ of length per $4,35 \pm 0,58 \mathrm{~cm}$ of diameter and $53,57 \pm 17,75 \mathrm{~g}$ of the fresh matter weight.

The mature seed is exalbuminous, and the embryo, with white coloration, is ellipsoid and slightly curved. It is constituted basically by the two fused fleshy cotyledons, evidenced for a small depression externally (Fig. 33). The suture that delimits them is more visible in sections (Figs. 32, 34 and 35). The radicle-hypocotyl axis is not very differentiated and just appears as a small protube- rance, below to the cotyledonar node (Figs. 32 and $33)$. The plumule is extremely reduced and completely covered by the united cotyledons, being visible, in longitudinal section, just as a conical protuberance, above to the cotyledons insertion (Fig. 34).

The testa is constituted by parenchymatic cells with thickened walls and by elongated sclerenchymatic fibers, both with lignified walls. The fibers accompany the vascular bundles, which are branched in all directions. 

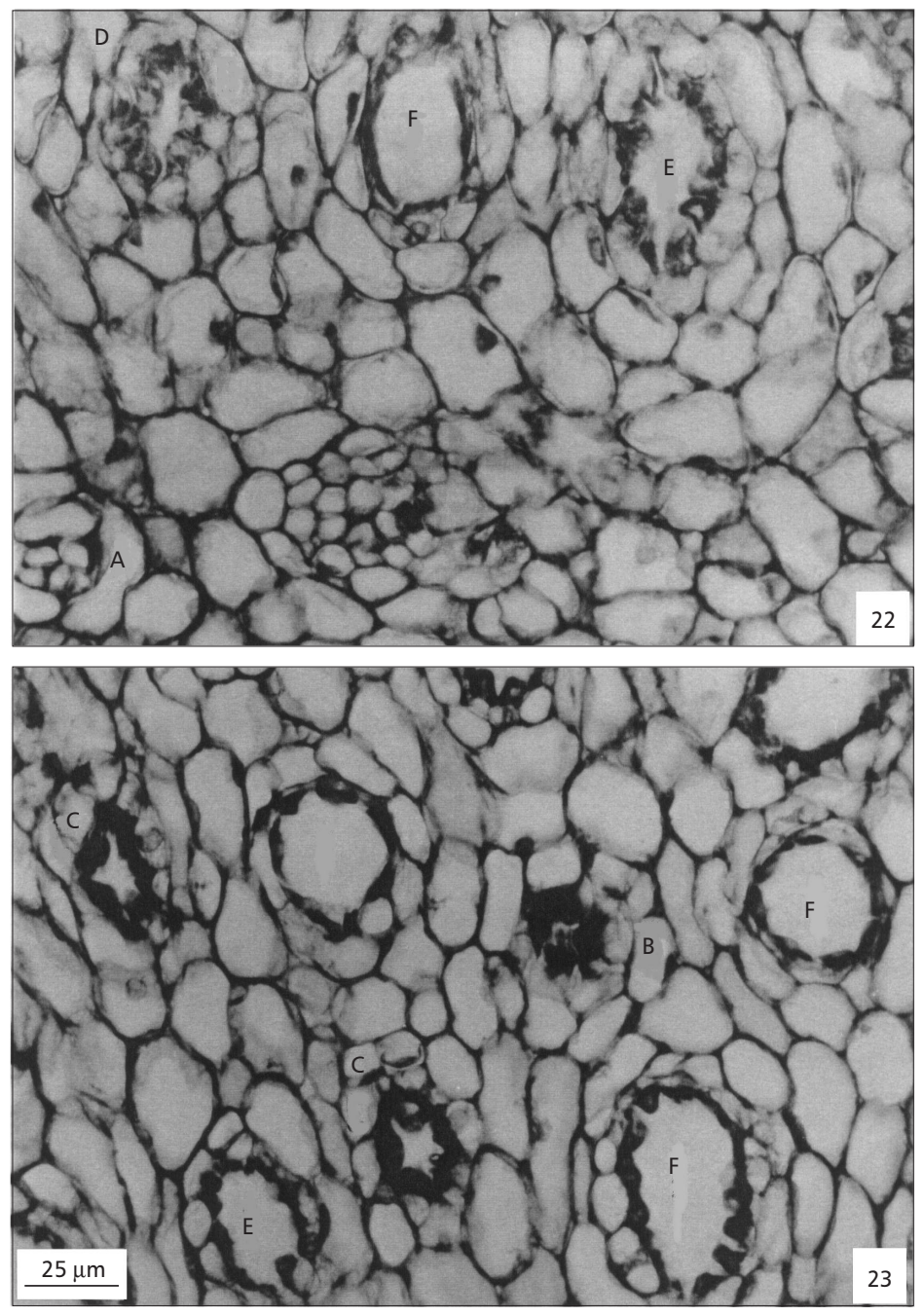

Figs. 22-23 - Mammea americana - Cross-section of the ovarian mesophyll evidencing secretory ducts in successive phases of differentiation (A to F).

This feature check to the seed its fibrous external aspect (Figs. 18, 31 and 32). In the embryo, the protoderm consists of small and cubic cells and the fundamental meristem already appears differentiated in a parenchyma with large and poliedric cells, which contain starchy.

Branched secretory ducts and vascular bundles are distributed longitudinally in the cotyledonar parenchyma (Figs. 34 and 35). The substance secreted by the ducts shows lipids and phenolic contents. Idioblasts with these contents also occur in the cotyledonar parenchyma.

\section{DISCUSSION}

The structure of the ovary of Mammea americana resembles that of another species of Clusiaceae, mainly because of the occurrence of secretory structures, like ducts in the ovarian mesophyll and mesocarp. This characteristic is evident in $P$. insignis (Moronobeoideae) (Mourão \& Beltrati, 1995a), in Vismia guianensis (Aubl.) Choisy (Hypericoideae) (Mourão, 1997) and in the pericarp of all the species of Clusiaceae described by Corner (1976). 

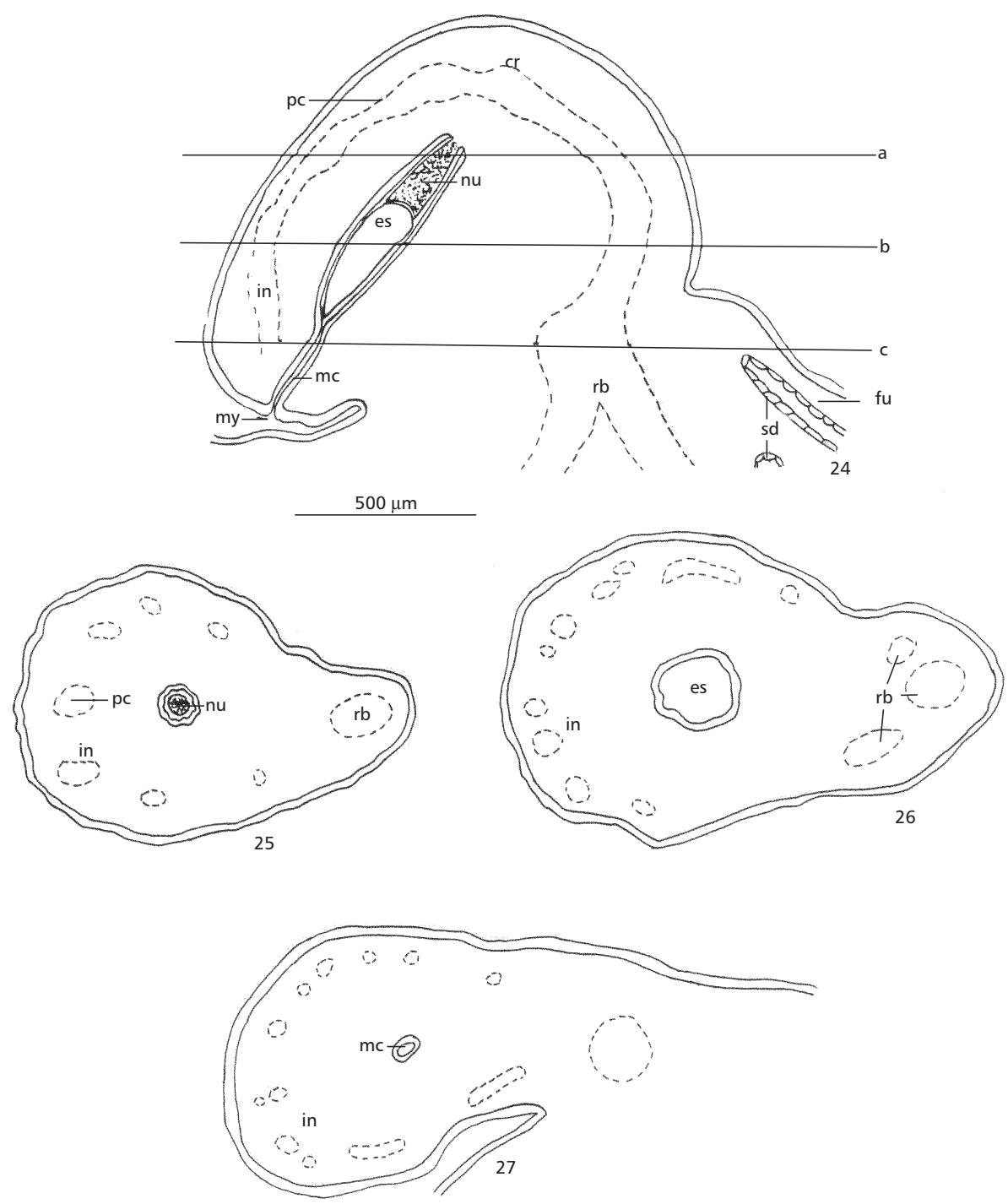

Figs. 24-27 - Mammea americana - Ovule. 24 - Longitudinal section. 25-27 - Cross-sections in a, b and c regions pointed in the Fig. 24, respectively. (cr - chalazal region; es - embryo sac; fu - funicle; in - integument; mc - micropyle channel; my - micropyle; nu - nucellus; pc - postchalazal ramification of the rapheal bundle; rb - rapheal vascular bundle; sd secretory duct.)

The definition of exo, meso and endocarp vary in agreement with each author. Most of the modern authors prefers to use the terms exo and endocarp in a wide sense, that includes respectively the external and internal epidermis and also some of the subepidermical tissues (Roth, 1977). In agreement with Fahn (1990), the separation of the pericarp in three distinct layers, makes easier the anatomical description, but they do not represent distinct layers according to their origin. In M. americana the exocarp arises from the outer epidermis and the first subepidermical layers of the ovarian mesophyll, which differentiate the periderm.

The endocarp development in Mammea americana resembles each that one described by Mourão \& Beltrati (1995a) in Platonia insignis (Moronobeoideae), except for the absence of the ventral meristem in this last one. 

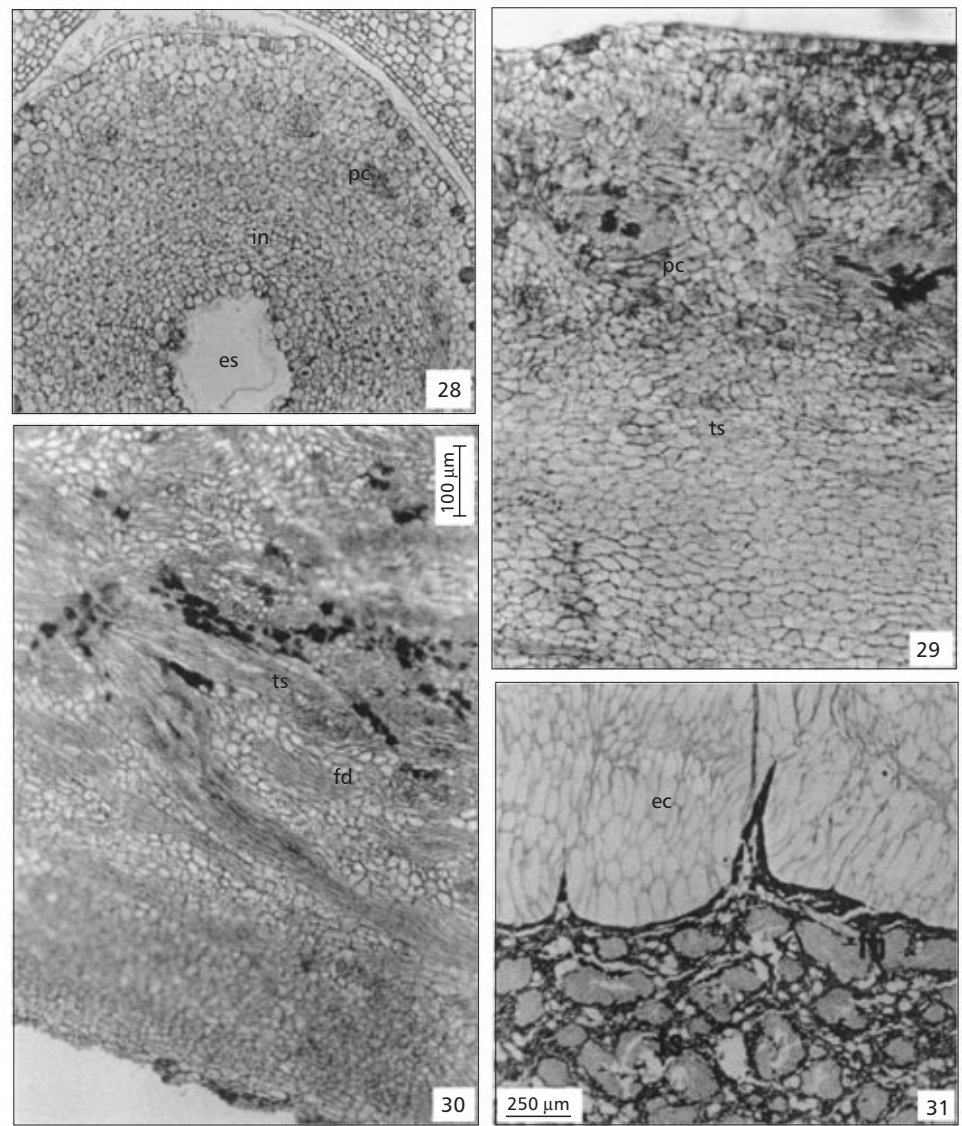

Figs. 28-31 - Mammea ameicana - Developing seed-coat. 28 - Ovule in cross-section. 29 - Young seed in cross-section evidencing the outer and medium region of the testa. 30 - Young seed in longitudinal section, evidencing the medium and inner part of the testa. 31 - Part of the mature seed and endocarp in cross-section evidencing the sclerotic mesotesta, projections of the exotesta and the endocarp firmly attached. (ec - endocarp; es - embryo sac; fb - fibers in differentiation; in - integument; pc - postchalazal vascular bundle; ts - testa.)

According to Roth (1977) the periderm formation in fruits is a relatively rare occurrence and usually associated to the secondary growth. The mature fruit can become eventually covered by a continuous layer of cork, originated of the activity of a phellogen. During the pericarp development of Mammea americana was observed until two peridermic layers with lenticels.

The anatomical characters of the pericarp of Mammea americana (Calophylloideae) are very similar to what was described by Cordemoy (1911) for Tsimatimia pervillei (Clusioideae - Garcinieae), by Sprecher (1919) for Garcinia mangostana (Clusioideae - Garcinieae) and by Mourão \& Beltrati (1995a, b) for Platonia insignis (Moronobeoideae).
Corner (1976) mentioned as characters of the Clusiaceae family the occurrence of anatropous and bitegmics ovules, pointing out that the vascular bundle in the ovule, either emits postchalazal branches or not.

However, in Mammea americana, the ovule are sharply unitegmic and the rapheal bundle when reaching the chalaza, branched by the whole outer region to the integument, until the proximity of the micorpyle. Postchalazals bundles were also observed in Platonia insignis (Moronobeoideae) by Mourão \& Beltrati (1995a). According to Johri \& Ambegaokar (1984) the vascular supply of the ovule is variable, being quite developed in primitive families. 


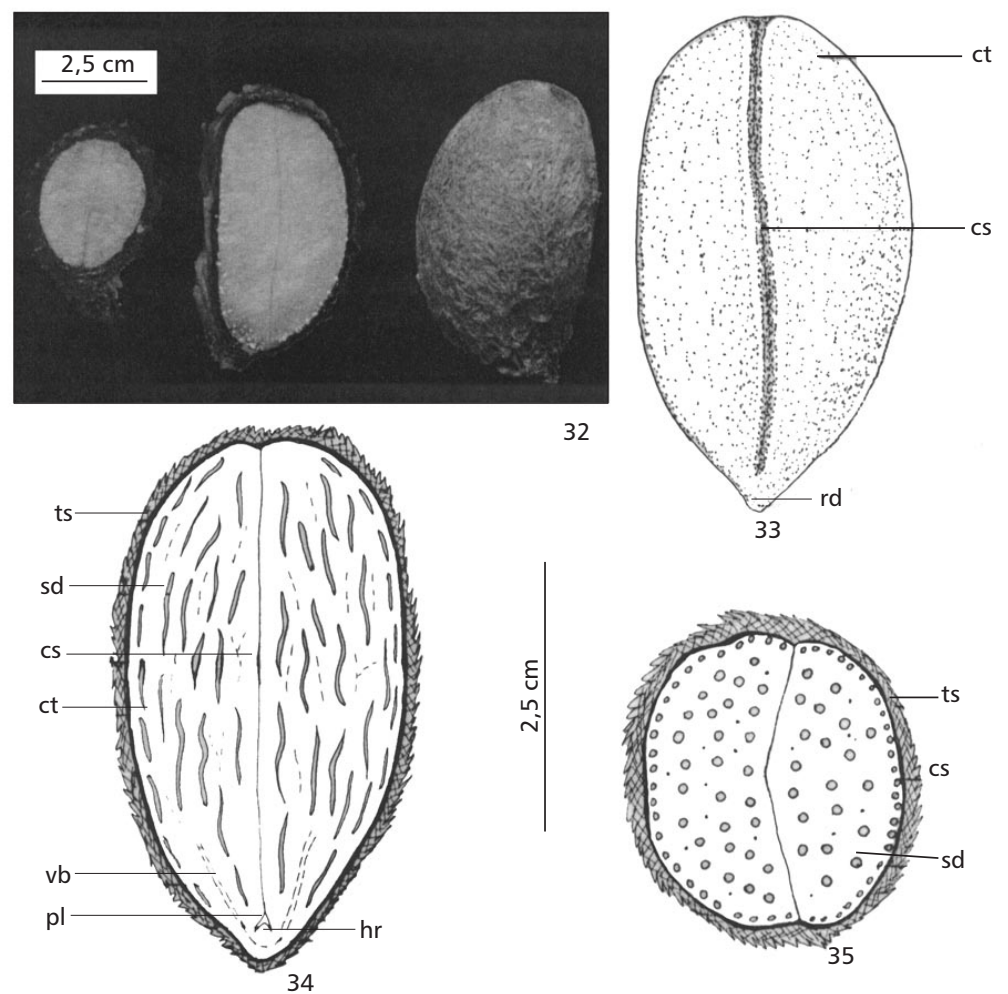

Figs. 32-35 - Mammea americana - Mature seed and embryo. 32 - Mature seed in cross-section (to the left), longitudinal section (to the center) and general aspect (to the right). 33 - General aspect of the embryo. 34-35 - Diagrams of mature seed in longitudinal and cross-section, respectively, evidencing the embryo. (cs - cotiledonar suture; ct - cotyledon; hr - hipocotyl-radicle axis; pl - plumule; rd - radicle; sd - secretory duct; ts - testa; vb - vascular bundle.)

The fruit and seed development in Mammea americana resembles that one presents in Calophyllum inophyllum (Calophlylloideae), described by Corner (1976). According to this author, in Calophyllum the woody layer of the fruit frequently interpreted as being the endocarp (Vaughan, 1970; Stevens, 1974; Vogel, 1980; van Roosmalen, 1985, Heywood, 1985; Spjut, 1994) constitutes the most external region of the testa. According to a recent fruit classification purpose to Barroso et al. (1999) the fruit of Mammea L. is included in the "drupóide-nuculânio" type. This fruit type according to these authors presents the pericarp layers clearly differentiated and the endocarp is lignified and constitutes several pyrenes.

The present study concluded that in Mammea americana, the yellow-reddish, fleshy and edible part of the fruit is constituted by the parenchymatic endocarp and the fibrous and lignified part is the seed integument. Therefore, the fruit of $M$. americana is a berry with mesotestal seed.

In the embryo classification purpose by Brandza (1908) and Guillaumin (1910) the embryo of $M$. americana is to the type III which characterizes the tribe Calophylleae. According to Martin (1946) embryo classification, the embryo of $M$. americana, occupies the totality of the seed volume being slightly curved. According to Barroso (1978) the embryo would be a pseudo-conferruminate type.

Acknowledgments - Are due to CAPES for financial support. Thanks are also due to Profa. Dra. Cássia Mônica Sakuragui (Universidade Estadual de Maringá, PR) for correcting the English. 


\section{REFERENCES}

BARROSO, G. M., MORIM, M. P., PEIXOTO, A. L. \& ICHASO, C. L. F, 1999, Frutos e sementes, morfologia aplicada à sistemática de dicotiledôneas. Editora UFV, Viçosa, 443p.

BARroso, G. M., 1978, Curso sobre identificação de sementes. CETREISUL, Pelotas (Mimeogr.).

BRANDZA, G., 1908, Recherches anatomiques sur la germination des Hypéricacées et des Guttifères. Ann. des Sci. Natur. Bot., série 9(8): 221-300.

CALZAVARA, B. B. G., 1970, Fruteiras: abieiro, abricozeiro, bacurizeiro, biribazeiro, cupuaçuzeiro. Instituto de Pesquisas e Experimentação Agropecuárias do Norte (IPEAN), Sér. Cult. da Amaz., 1(2): 46-84.

CORDEMOY, M. H. J., 1911, Contribution a l'étude de la structure du fruit et de la graine des Clusiacées. Ann. du Mus. Colon. de Mars., 2(9): 1-22.

CORNER, E. J. H., 1976, Clusiaceae, pp. 97-103 (1 ${ }^{\text {st }}$ vol.), pp. 92-111 (2 ${ }^{\text {nd }}$ vol.). In: E. J. H. Corner, The seeds of dicotyledons. University Press, Cambridge.

ENGLER, A. \& KELLER, R., 1925, Guttiferae, pp. 154-237 ( $21^{\text {st }}$ vol.). In: A. Engler \& K. Prantl, Die naturlichen Pflanzenfamilien. Verlag Wilhelm Engelmann, Leipzig, $2^{\text {nd }}$ ed.

ENGLER, A., 1888, Guttiferae, pp. 381-474, t. 79-108. In: von. C. F. P. Martius, Flora Brasiliensis, vol. XII, pars. I (fasc. CII)

FAHN, A., 1990, Plant Anatomy. Pergamon Press, Oxford, $643 \mathrm{p}$.

GUERRITS, P. O., 1991, The application of glycol methacrylate in histotechnology; some fundamental principles. Department of Anatomy and Embriology, Gröningen, Netherlands.

GUILLAUMIN, A., 1910, L'étude des germinations appliquée à la classification des genres et a la phylogénie des groupes. Rev. Gén. de Bot., 22: 449-468.

HEYWOOD, V. H. (ed.), 1985, Flowering plants of the world. Croom Helm, London, 336p.

HUBER, J., 1904/1906, Notas sobre a pátria e distribuição geográfica das árvores frutíferas do Pará. Bol. do Mus. Par. Emilio Göeldi de Hist. Nat. e Ethnog. Belém, 4: 375406.

JENSEN, W. A., 1962, Botanical histochemistry: principles and pratice. W. H. Feeman, San Francisco, 408p.

JOHANSEN, D. A., 1940, Plant microtechnique. Mc GrawHill Book, New York, 523p.

JOHRI, M. B. \& AMBEGAOKAR, K. B., 1984, Embryology; then and now, pp. 1-4. In: M. B. Johri (ed.), Embryology of Angiosperms. Springer Verlag, Berlin.

MARTIN, A. C., 1946, The comparative internal morphology of seeds. The Amer. Midl. Natur., 36(3): 513-660.
MELCHIOR, H., 1964, Guttiferae (Clusiaceae), pp. 170-173 (vol. II). In: Engler, A., Syllabus de Planzenfamilien. Gebruder Borntraeger, Berlin, Nikolassu.

MOURÃO, K. S. M. \& BELTRATI, C. M., 1995a, Morfologia dos frutos, sementes e plântulas de Platonia insignis Mart. (Clusiaceae). I. Aspectos anatômicos dos frutos e sementes em desenvolvimento. Acta Amazônica, 25(1/2): 11-32.

MOURÃO, K. S. M. \& BELTRATI, C. M., 1995b, Morfologia dos frutos, sementes e plântulas de Platonia insignis Mart. (Clusiaceae). II. Morfo-anatomia dos frutos e sementes maduros. Acta Amazônica, 25(1/2): 33-46.

MOURÃO, K. S. M., 1997, Morfologia e desenvolvimento dos frutos, sementes e plântulas de Vismia guianensis (Aubl.) Choisy e Mammea americana L. (Clusiaceae Lindley). Tese de Doutorado, Unesp, Rio Claro (SP-BR), 156p.

O'BRIEN, T. P., FEDER, N. \& McCULLY, M. E., 1965, Polychromatic staining of plant cell walls by toluidine blue O. Protoplasma, 59: 368-373.

PIO CORRÊA, M., 1926, Dicionário das plantas úteis do Brasil e das exóticas cultivadas. Ministério da Agricultura, Rio de Janeiro, 1ํㅡㄴ.

RADFORD, A. E., DICKINSON, W. C., MASSEY, J. R. \& BELL, C. R., 1974, Vascular plant systematics, Harper \& Row Publishers, New York, 891p.

RODRIGUES, R. M., 1989, A flora da Amazônia, CEJUP, Belém, 462p.

ROTH, I., 1977, Fruits of Angiosperms, 10 ${ }^{\text {th }}$ vol., 666p. In: Encyclopedia of plant anatomy. Gebruder Borntreger, Berlin.

SCHMID, R., 1986, On cornerian and other terminology of agiospermous and gymnospermous seed coats: historical perspective and terminological recommendations. Taxon, 35(3): 476-491.

SPJUT, R. W., 1994, A systematic treatment of fruit types. Memo. of the New York Bot. Gard., 70: 1-82.

SPRECHER, M. A., 1919, Étude sur la semence et la germination du Garcinia mangostana L. Rev. Génér. de Botan., 31: 513-531.

STEVENS, P. F., 1974, A review of Callophyllum L. (Guttiferae) in Papuasia. Australian Journal of Botany, 22: $349-411$.

VAUGHAN, J. G., 1970, The structure and utilization of oil seeds. Chapman and Hall Ltda., London, 279p.

VAN ROOSMALEN, M. G. M., 1985, Guttiferae. In: Fruits of the Guianan Flora. Institute of Systematic Botany, University, Silvicultural Department of Wageningen, Agricultural University, Utrecht, Netherlands, 483p.

VOGEL, E. F. de, 1980, Seedling of dicotyledons. Center Agric. Publ. Doc. Wagerningen, Netheerlands, 471p. 